\section{Animal Welfare Law: Foundations for Reform}

\author{
Philip Jamieson \\ Canberra, Australia
}

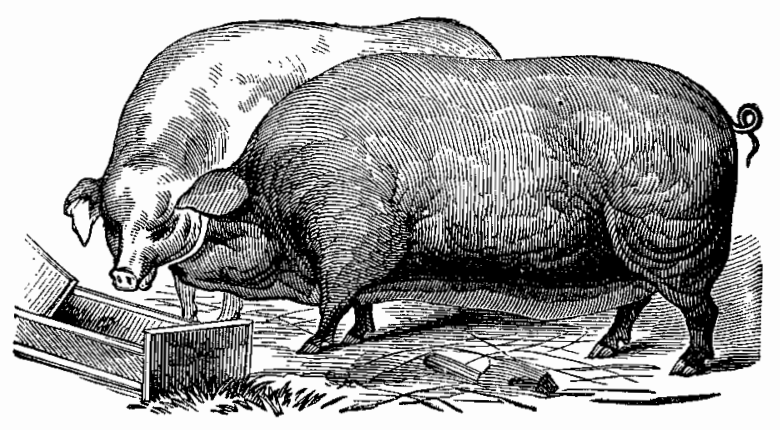

"The greatness of a nation and its moral progress can be judged by the way its animals are treated"

Mahatma Ghandi (1972)

Inspired by the resurgence of interest in the nature of the relationship between humans and animals dating to the publication in 1975 of Victorian philosopher Peter Singer's utilitarian-based book, Animal Liberation, ${ }^{1}$ there have been significant developments in Australian animal welfare law within the last ten years. At the Commonwealth level, the Senate Select Committee on Animal Welfare was established in 1983, issuing its most recent report, on Intensive Livestock Production, in June, 1990. The States of New South Wales, Victoria, and South Australia have all recently introduced complete revisions of their animal cruelty legislation, while Queensland and the Australian Capital Territory are presently reviewing their existing provisions.

In the context of this ongoing movement in reform of Australian animal welfare law, the rationale underlying the existing law needs to be identified to better understand what is in the push for what ought to be.

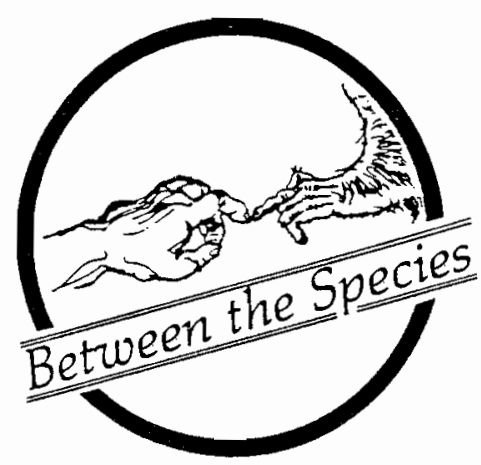

In the legislative and judicial history of our animal welfare law, four considerations have been variously identified to explain the existence and form of those laws:

1. the "Dominion" rationale;

2. the Kantian thesis;

3. the intrinsic value of an animal;

4. human sentiment.

\section{The "Dominion" Rationale}

Humankind's biblical "dominion" was important in the early formulation and construction of animal cruelty legislation.

It has often been suggested that the integration into Judaeo-Christian theology of Greek philosophy served to establish that "dominion" as both despotic and anthropocentric. ${ }^{2}$ Nevertheless, legislative and judicial consideration of the rationale for animal cruelty legislation during the nineteenth century not infrequently invoked humankind's biblical "dominion,"3 on occasion even citing scripture to this effect. ${ }^{4}$ That the biblical basis of humankind's "dominion" falls short of simple despotism over the animal creation seems to have been well accepted by both legislature and judiciary throughout the nineteenth century.

Nevertheless, there remained no unanimity in the interpretation of what that more humane "dominion"

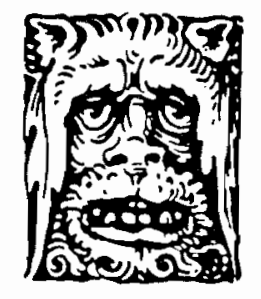


should involve. At one extreme, characterized as "responsible dominion," humankind should respect the animal creation, though human interests remain trumping in any conflict with the welfare of animals. At the other extreme, humankind is charged with the responsibility of keeping "God's garden" as His "representative on earth" allowing of no interference with the animal creation in giving effect to human interests. ${ }^{6}$

Somewhere between these two extremes would we find the appropriate nature of our relations with animals. In the history of the animal cruelty laws, humankind's biblical "dominion" has never been effected by legislation reflective of a philosophy of "stewardship" allowing of no interference with the animal creation in the fulfillment of human interests. It was as against humankind's "cruel and oppressive treatment of ... animals" that Lord Erskine invoked the obligations of our biblical "stewardship" in the preamble to his unsuccessful Bill for "Preventing Wanton and Malicious Cruelty to Animals" in 1809.? In the interpretation of that notion of "cruelty," the animal cruelty laws have inevitably employed the concept of "unnecessary" suffering. This has legitimated the fulfillment of human interests where such would nevertheless cause suffering to animals provided only that that suffering be "necessary" within the meaning of the legislation.

The courts, in invoking humankind's biblical "stewardship" to explain the legislation during the nineteenth century, were never able to adopt a construction of the legislation that it could not bear, i.e., that allowed of no interference with the animal creation in the expression of human interests. Rather, it being clear that "necessary" interference was expressly contemplated by the legislation, the courts sought to define the content of that "stewardship" somewhere further along the spectrum toward "responsible dominion."

While agreed that a "line must be drawn somewhere," the courts disagreed about where it should be drawn. The religious influence was strongest amongst the Irish judiciary. Nevertheless, it was the Irish judiciary who construed the legislation as effecting merely a "responsible dominion." Human interests were perceived as inevitably trumping the welfare of animals. While "the lower animals are not to be entirely subordinated to man"9 they are nevertheless to serve human interests in effecting "the objects for which cattle were given to man." 10
"Responsible dominion," respecting nature but subject to the supremacy of human interests in seeking "proportion between the object and the means," has characterized much of the history of the construction of the animal cruelty legislation. Nevertheless, it has not inevitably done so. The English judiciary were more equivocal than the Irish in invoking theological precepts to explain the legislation. They were nevertheless unprepared to conclude of any human interest (economic or otherwise) that its fulfillment made "necessary" any consequent animal suffering. Dehorning cattle, for example, legitimated by the Irish courts, ${ }^{12}$ was found cruel by the English, ${ }^{13}$ the element of commercial profit to the owner being considered insufficient to justify the practice.

Such a philosophy has surfaced in the history of legislative ${ }^{14}$ and judicial ${ }^{15}$ thinking in England. Its expression has nevertheless remained merely occasional. On the question of dehorning itself, the practice, important to the Irish economy, had "for twenty years ... been entirely disused throughout England."16 In Australia, as in Ireland, the practice was one important to the economy of a country substantially dependent on the activities of its rural sector. It was expressly exempted from the operation of the legislation in virtually all Australian States (with the exception of Victoria, the least rural of the States) in the early twentieth century. ${ }^{17}$ The history of the Australian animal cruelty legislation has been to allow that economic considerations alone have been sufficient to justify otherwise cruel practices. Occasional indications of a more enlightened philosophy are today becoming more clearly articulated, particularly in relation to the rural community and medical experimentation. ${ }^{18}$.

Nevertheless, the theological justification for human consideration of the welfare of animals in terms of humankind's biblical "dominion," not infrequently invoked legislatively and judicially during the nineteenth century, has today fallen from favor.

"In Australia little or no debate has occurred as to the relationship between religion and the animal liberation movement."19

It is not within the realm of theology that the current debates are taking place, nor have they done so during the course of the twentieth century. Such debates, apparent in the early history of the animal cruelty legislation, have appeared in neither legislative nor 
judicial considerations for nearly a century. It appears to have neither legislatively nor judicially any perceived role in the further reform of Australian animal "entity" law. ${ }^{20}$

\section{The Kantian Thesis}

It is to Kant's "escalation" thesis-that cruelty to animals brutalizes humans in their attitudes toward one another - that legislative and judicial consideration of the rationale for animal cruelty legislation has for the most part fallen. Although the "demoralization of the people" appears in the preamble to the English legislation only in $1835,{ }^{21}$ the "evident tendency [in cruelty] to harden the heart against the natural feelings of humanity" had figured, in conjunction with the "dominion" rationale, as early as 1809 in Lord Erskine's unsuccessful Bill for "preventing Wanton and Malicious Cruelty to Animals." 22 Popular in judicial analyses of the legislation during the nineteenth century, but with equivocal support in Australian courts in the twentieth, this rationale has continued to appear in judicial analyses in the United States even in recent years. ${ }^{23}$ Embodied in the "doctrine of moral improvement" it has also characterized the development of the charitable animal welfare trust during the twentieth century, receiving expression most recently in Canada. ${ }^{24}$

\section{Background to Kant's Escalation Thesis}

Kant, the German philosopher of the Enlightenment, had articulated this thesis in following a tradition begun in Greek moral thought and later brought within the purview of Western moral thinking by Aquinas. He had been led to this thesis in his analysis of rationality as the single most important, morally relevant characteristic.

"Rationality" he locates in the capacity for moral legislation. That capacity is an end in itself, to be pursued through the autonomous act of the individual will. It is our function to be rational in all aspects of our lives in respecting rationality as an end and not merely as a means to an end. Since humans are the only rational beings, this leads Kant to his "Categorical Imperative," or basic moral law, that you should "[a]ct in such a way that you always treat humanity, whether in your own person or the person of any other, never simply as a means, but always at the same time as an end." 25
Since "the dog cannot judge,"26 animals being "nonrational [have] only a relative value as means and are consequently called things." 27 Kant's consideration of the value of animals is instrumental. To them "we have no direct duties." ${ }^{28}$ On what basis might we nevertheless have indirect duties toward animals? It is this question which leads Kant to the formulation of his escalation thesis: We must "practice kindness toward animals, for he who is cruel to animals becomes hard in his dealings with men .... Tender feelings towards dumb animals develop human feelings towards mankind."29

There is empirical evidence supporting the validity of this escalation thesis. Studies have suggested that "childhood cruelty towards animals may operate as one component of a behavioural spectrum associated with violence and criminality in adolescence and adulthood." ${ }^{30}$ In combination with persistent enuresis and firesetting, "animal cruelty appears to be part of a triad in childhood which may be associated with dangerous aggression against others at a later age." ${ }^{.1}$ Moreover, research has suggested a human "tendency to evaluate others in light of their interactions with animals," 32 further supporting in a more general sense the thesis that our attitudes toward animals are important in shaping our attitudes toward one another. ${ }^{33}$

Using the escalation thesis to explain the existence of animal cruelty legislation has an obvious appeal to those opposed to the notion of the "moral rights" of animals. It delimits its justification to the realm of merely instrumental considerations toward animals.

The dilemma with this obvious appeal to explain the existence of animal cruelty legislation was early exposed by Joseph Ritson, who noted that "those accustom'd to eat the brute, should not long abstain from the man." ${ }^{34}$ If we are to learn from our treatment of animals how we should treat people, animal cruelty legislation embodying the differential classification of animals according only to the economic viability of that protection must imply that we may treat people similarly.

The implications for our legal system of such a thesis are clearly unacceptable. It would allow that people might be treated merely as objects of our property law system. There are already elements of such a philosophy in our legal system. The services of professional athletes (especially football stars) are regularly sold by their proprietors. Professional baseball plays in the United States (like indentured servants and serfs) had until recently no choice in the sale-the reserve clause of 
their contracts enabling their proprietors unfettered freedom in the sale of their services. ${ }^{35}$

The differential treatment of animals under legislation has unpalatable implications quite separate from its potential for escalation to the economic treatment of human beings. Canadian neurosurgeons who had involved themselves in animal experimentation during a year's sabbatical were reported to have taken quite some time to regain empathy with their patients' suffering when they returned to doctoring. ${ }^{36}$

Using the escalation thesis to explain our existing animal cruelty legislation clearly has implications detrimental to the public benefit. Although formulated in terms of the "doctrine of moral improvement" in the law of charity, it nevertheless finds no support there either, human welfare, unlike that of animals, having of itself never been considered charitable. ${ }^{37}$ The community's morals it seems are not thought by the courts to be elevated in the same way by diminishing cruelty to humans as by diminishing cruelty to animals. Nor does it have any appeal in considering the nature of the noncharitable purpose trust for a particular animal. Under a variant of the "escalation thesis," such trusts might be thought to survive on the basis of the public benefit in encouraging kindly action toward animals. Yet it is the absence of public benefit that prevents such trusts being held to be charitable. That such trusts are not struck down by the courts cannot find its justification in any variant of the escalation thesis.

While popular in legislative and judicial thinking and supported by empirical evidence as to its validity, Kant's escalation thesis, as an explanation of the rationale underlying animal "entity" law in Australia, is substantially inadequate. If applied in the context of our existing animal cruelty legislation, it brings with it unpalatable implications for our community, and in respect of the law as to wills and trusts it cannot be applied in any way that forms a coherent explanation of the present form of that law.

\section{Intrinsic Value}

There is some judicial support for the view that the existing animal welfare law recognizes the intrinsic value of an animal. Courts in the United States in the latter part of the nineteenth century on occasion found in the existence of animal cruelty legislation "the theory, unknown to the common law, that animals have rights which, like those of human beings, are to be protected." 38 The legislation was seen as an attempt to "recognize and ... protect some abstract rights in all that animate creation made subject to man." 39 Even in recent years, courts in the United States have apparently referred to the "moral rights" of animals as, for example, in a Memorandum Opinion and Order issued in the General Sessions Court at Kingsport, Tennessee, in $1983^{40}$ and in Caper's Estate (1964) ${ }^{41}$ actually quoting a passage from Albert Schweitzer's Out of My Life and Thought on the ethics of a concern for the sacred nature of life.

In the United States there is also recent legislative support for this view, the California Senate resolving in 1979 that "the Legislature of the State of California should take effective measures to protect and defend the rights of animals." 42

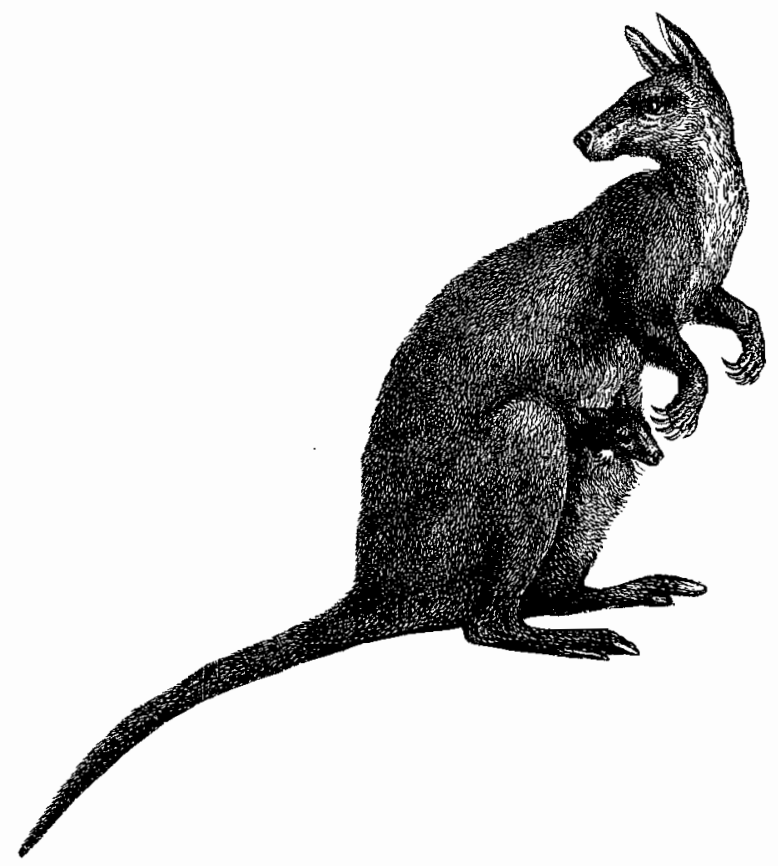

The intrinsic value of an animal, recognized in these occasional ascriptions of "moral rights" in the United States, also appears to be recognized in the nature of the most recent movements in reform of Australian animal welfare law. The Report by the Senate Select Committee on Animal Welfare: Animal Experimentation 1989 concludes, having devoted nearly twenty pages of its report to the consideration of the moral status of animals, that: 
Through animal cruelty ... legislation, society has acknowledged that animals ... have certain claims or interests which may be expressed as rights, that are afforded protection. When rights of animals come into conflict with those of humans, the rights of one will normally succumb to the other. Although humans rights have usually predominated in such conflicts, each case should be examined on its merits and human rights should not automatically prevail. ${ }^{43}$

The Report merely evidences "changing community attitudes towards animals" 44 in Australia with "an increase in the demonstrable concern for all living beings." 45 That change, under which a moralistic outlook on animals is now as popularly held as the previously predominant utilitarian perspective, ${ }^{46}$ has seen a British public opinion poll in recent years suggest that $9 \%$ of the population would even be prepared to change their voting habits on the issue of animal welfare. ${ }^{47}$ Despite a limited moralistic and pronounced utilitarian outlook toward animals amongst the rural community generally, ${ }^{48}$ a 1981 survey of Australian farmers revealed that $87 \%$ in fact "recognized that cases of cruelty and mistreatment of animals are still widespread in agriculture." 49

This change in attitude appears to be evident in recent legislative reform of Australian animal welfare law. One purpose of the Prevention of Cruelty to Animals Acl 1986 (Vict.) is expressed as the prevention of cruelty to animals, without qualification as to an instrumental basis for the object. ${ }^{50}$ While equivocal therefore as to the implications of this expressed objective, the legislation itself lends support to an intrinsic analysis. By that legislation, farming practices are required to comply with relevant Codes of Practice. ${ }^{51}$ Although challenged as failing to recognize the fundamental economic importance of the rural community to the State, ${ }^{52}$ the legislation was passed. Regulations introduced in that same year under the South Australian legislation prescribed various Codes of Practice to operate within the rural sector, recognizing as the "basic requirement for the welfare of" animals "a husbandry system appropriate to their psychological and behavioural needs." 53

In similar terms, the most recent revision of the Australian Code of Practice for the Care and Use of Animals for Scientific Purposes ${ }^{54}$ imposes the obligation to consider the animal's "welfare as an essential factor," 55 providing, for example, confinement of the animals by means that "ensure [its] comfort and wellbeing," taking into account such factors as its natural environmental and behavioural requirements. ${ }^{56}$

Such reforms are also evident internationally, the Animal Protection Act (1988: 534) (Sweden), for example, seeking to ensure that both urban and rural domestic animals are provided with environments that "allow the animals to behave naturally."57

These recent revisions of the law recognize the need to make technology meet the needs of the animal rather than the reverse. In doing so, they appear to give legislative force to the theories of those who would advocate the intrinsic value of the animal's well-being. ${ }^{58}$ The most satisfactorily articulated of these is Bernard Rollin's use of the telos of a being, as identifying the characteristic giving rise to the possession of "moral rights." By it, animals are not measured "according to scales that compare them to human beings." 59 Rather, it advocates, as the most recent legislative reforms appear to do, that we should recognize their own biologically determined natures in determining the morality of our treatment of them.

Of course, these legislative reforms, protecting animals in terms of their own natural needs, might well be explained on purely instrumental grounds. For example, the recognition of their natural needs may make us more likely to recognize the needs of members of our own communities. However instrumentally justified though, this type of reform is an answer to the unpalatable consequences identified in the application of Kant's escalation thesis to the more traditional form of animal cruelty legislation and is, in any event, consistent with the type of reform advocated by many of those philosophers who have sought the moral consideration of animals for their own sakes. On the other hand, this legislation may well be construed as a far-sighted attempt to recognize the natural needs of animals as morally considerable in their own right and in the absence of purely instrumental considerations.

The natural needs of animals have been the focus of little attention historically in either the drafting or subsequent judicial construction of our animal welfare laws. While animal cruelty legislation has on occasion acknowledged "the duty of every person having the care or charge of any animal to take all reasonable steps to ensure [its] well-being," ${ }^{0}$ the recognition of that duty 
has been dependent upon the ambit attributed to "necessity" in the construction of the animal suffering permitted by the legislation.

\section{Dependency from Domestication}

A theory, although advanced in advocation of reform, which serves well in explaining the established form of the animal "entity" laws is that which grounds the intrinsic value of animals in their dependency from domestication. ${ }^{61}$

Whether animals have been domesticated as pets, servants, sources of food and clothing, or as human surrogates in experimental research, their social need to belong to a group has remained a fundamental biological imperative. ${ }^{62}$ We have simply shifted that bond of social dependence to the animal's owner. It is " $t \mathrm{t}$ hrough this exploitation of the animal's own drive to belong [that] there emerges a relationship with the proprietor that is qualitatively different from the mere owner-owned relationship." 63

Having been "brought directly into the human social unit," it has been suggested that we "would seem to have no alternative but to treat it as a functioning member of that social unit," 64 to be ascribed rights in the same manner as in the case of "marginal humans." In both instances the recipient of those rights is a powerless member of our community whose interests are to be protected against the exploitation of the more powerful. The view that domestication is a morally relevant factor in conferring moral standing on animals has been considered to be "sufficiently persuasive to be worth more investigation." 65

Such a theory might rationalize even the existing law in terms of the intrinsic value of animals. If wild, there being no acquired moral status from domestication, the animal has no "moral rights" whatever protections may be instrumentally justified. ${ }^{66}$ Its case for moral consideration is the stronger the greater its dependency from the fact of its domestication. While wild animals benefit from merely negative obligations of noninterference under the animal cruelty legislation, affirmative obligations toward their animals are additionally imposed on the owners of domesticated animals. Those obligations are greater in the case of companion animals, most dependent on their owners for their welfare, then in the case of merely rurally domesticated animals. The recognition of the noncharitable purpose trust has similarly arisen only in the context of companion animals, its operation more broadly being highly questionable.

Nevertheless, the theory that moral status should arise in the context of domestication has been advocated in justification of reform of the existing law. Its proponents would not, for example, see in its terms justification for the general exemption of "accepted farming practices" from the operation of the animal cruelty laws, a position which has historically characterized the legislation of the Australian States. Nor does it explain the position of experimental animals within the legislation, historically granted limited protections while completely dependent as a result of domestication.

\section{Human Sentiment}

While the most recent reforms in Australian animal welfare law may be suggestive of a recognition of intrinsic value as inhering in animals, carrying with it "moral rights" to the recognition of biologically determined natural needs, no similar account seems adequate to explain the traditional form of our animal "entity" laws. In explanation of their underlying rationale, instrumental rather than intrinsic considerations seem evident. Nevertheless, we have identified no clearly authoritative account of that instrumental explanation.

In humankind's affections for animals, Aquinas identified either reason or sentiment at their base. ${ }^{67}$ Reason, expressed in the Kantian escalation thesis, ${ }^{68}$ has failed to explain our legal expression of those affections. While contemporary moral philosophy strongly favors rationalistic theories, sentiment has figured prominently in the judicial analyses of animal cruelty and wills and trusts laws.

Sentiment has appeared in courts in Scotland, the United States, and South Africa in the analysis of animal cruelty legislation. ${ }^{69}$ In courts in both Australia and England, it has been mooted in explanation of the anomalous recognition of the noncharitable purpose trust, ${ }^{70}$ and in the United States sentiment has featured in the judicial construction accorded both testamentary pet destruction provisions ${ }^{71}$ and in the award of damages for wrongful destruction of an animal. ${ }^{72}$ When in Smith $v$ Avanzino ${ }^{73}$ more than 3000 letters were received by the court in expressing a "well-defined and universal sentiment" "74 that the public looked with "disfavour... [upon] the decree that the decedent had for her dog,"75 
a special statute was even enacted, rushed through the California legislature in order to save the dog's life. ${ }^{76}$

Sentiment has the merit of providing a coherent explanation of the form of the existing animal "entity" laws. The differential protection of animals embodied in the legislation appears to be directly proportionate to the strength of the human/companion animal bond. Those animals that perform a companion role as human pets and with which we form our closest emotional attachments are those which have received the most extensive protection under animal cruelty legislation. Specific exemptions have operated in relation to our activities with respect to food and research animals, our relations with these animals not being characterized by the same personal and familial ties that characterize the human/companion animal bond and for whom no clearly defined public sentiment analogous to that arising from that bond exists. The philosophy underlying our animal "entity" laws appears best described as based merely on human sentiment, laws "intended ... to save ... people of common good feeling, the pain of witnessing [animal] sufferings."77

A justification of such laws based on human sensibilities, while adequate to explain the French "Loi Grammont," has been argued to be inadequate to explain the prevention of even private and unobserved cruelty to an animal under our own legislation. ${ }^{78}$ However, one's sensibilities are perhaps no less offended by the knowledge of the occurrence of such private activities then they are by the witnessing of them. Professor Louis Schwartz, one of the architects of the United States Model Penal Code, has identified sentiment as the rationale behind the legislation:

\section{Our concern is for the feelings of other human beings, a large proportion of whom, although accustomed to the slaughter of animals for food, readily identify themselves with a tortured dog or horse and respond with great sensitivity to its sufferings. ${ }^{79}$}

While a utilitarian attitude of valuing animals in terms merely of their practical and material value has characterized twentieth century perceptions of animals, ${ }^{80}$ the humanistic perspective of a strong affection for animals has become predominant in more recent years. The most common attitude toward animals among children ${ }^{81}$ and young adults ${ }^{82}$ is a humanistic perception of animals that has become far more prevalent in urban environments than the utilitarian attitude, particularly in recent years. ${ }^{83} \mathrm{~A}$ study in the United States suggests that two-thirds of the American population have owned pets "as dear to them as another person." 84 In rural environments, on the other hand, where the human/companion animal bond does not characterize the attitudes of owners toward their stock, farmers are still highly utilitarian in their outlook on animals. ${ }^{85}$

Sentimental affections toward animals have achieved a prominence in current community attitudes toward animals. They are both sufficient to explain the existing form of animal "entity" law and are not infrequently advanced by the courts to explain its underlying rationale. What place have such sentimental affections in our moral system?

Sentimentalism has recently been described as having "no very clear shared sense either in current moral theory or in the history of ethics." 86 Appeals to sentiment have often been avoided by philosophers in the animal welfare debate, fearing criticism of their writing as purely emotive and not worthy of serious consideration. ${ }^{87}$

Nevertheless, in recent philosophical writings (particularly in the context of the animal welfare debate) there has been a resurgence of interest in the place of sentiment in a moral system. ${ }^{88}$ Discussion of the subject has centered on the writings of such as Shaftesbury, Hutcheson, Hume, and Smith. Each sought to anchor moral motivation and justification not in reason but in an appeal to emotions, desires, and sentiments.

One difficulty in interpreting their writings derives from variation in the meaning to be attributed to terminologies they used. In their use of "sympathy," for example, neither Hume nor Smith employed the term in its generally accepted modern sense, our feeling of compassion or pity for the suffering of another. ${ }^{89}$ For Hume, it is more than the mere sense of "compassion" or "pity," being closer in meaning to empathy, actually understanding the feelings of another whatever be our own feelings in the matter. ${ }^{90}$ It is a matter of shared feelings, a sense of feeling with another.

In Smith's writings, not even this accurately characterizes his use of "sympathy." He argues that more must be involved than merely the emotionally neutral reception of that other's feelings, for otherwise there could never then be an absence of sympathy upon which to base judgments of disapproval. Rather, my sympathies derive from an enlivening association of 
my own sympathetic feelings with the feelings of the other. The coincidence of our sentiments is brought about by my capacity to sympathize with another through imaginary change of position, conceiving myself to be in that other's position and comparing with my own sympathetic feelings the real feelings of that other. ${ }^{91}$

Nor does either Smith or Hume see sympathy as sentiment. For Hume, the idea of a sentiment is "so enlivened [through the mechanism of sympathy] as to become the very sentiment." ${ }^{\text {"92 }}$ For Smith, sympathy is merely the correspondence between sentiments of pity, compassion, or sorrow..$^{93}$

Their concepts of sympathy and sentiment fail to accord with the more usually understood meanings of the terms, even in their own day. It is therefore difficult to context within the sentimentalist framework the many and various judicial references to sympathy ${ }^{94}$ and sentiment ${ }^{95}$ to explain the animal "entity" laws.

Nevertheless, both Hume and Smith discussed animal sympathy in developing their theories. Since for Hume good and evil are not simply "matters of fact" but are to be found in one's "own breast," the evil of an action arises purely because "from the constitution of your nature you have a feeling or sentiment of blame from the contemplation of it." ${ }^{96}$ Decrying the rationalists of the European Continent, David Hume brought the empirical philosophies of Locke and Berkeley to their logical conclusions. Animal suffering was self-evident, and its evil lay in the sentiment evoked from its contemplation. While Hume did not consider that we are called on to act justly toward animals, he concluded that we "should be bound by the laws of humanity to give gentle usage to these creatures."

Similarly for Smith animals were not only the causes of pleasure and pain but also capable of feeling those sensations. ${ }^{98}$ They are, therefore, "less improper objects of gratitude and resentment than inanimated objects," 99 though still far from being complete and perfect objects of those passions. For this, they would need to be capable not only of producing sensations of pleasure and pain but also of doing so from design. ${ }^{100}$ As regards animals, therefore, Smith concludes that our passions of gratitude and resentment, while present, nevertheless "still feel that there is something wanting to their entire gratification."101

Animals are, therefore, for both Hume and Smith, at least in some sense, proper objects of sentimental concern. It is in this sense perhaps that the courts have perceived in animal cruelty legislation its usefulness in "elevating humanity by enlargement of its sympathy with all God's creatures." 102

In what degree our sentiments are legitimately motivated by our sentimental concern for the welfare of animals has been the subject of recent philosophical writings. The American philosopher, Steve Sapontzis, has acknowledged the argument (in responding to it) that in community life, "[w]e are not only permitted but even obligated to give priority to the interests of our families, friends, colleagues and compatriots ... a world from which these non-egalitarian commitments were abolished would not be enhanced but be impoverished." 103 On this view, "speciesist tendencies ... are [actually] consequences ... of moral excellence. The fact that we can find no reason for speciesism when we consider the consequences, or the morally relevant characteristics of animal vis-à-vis some humans, is irrelevant." 104

In responding to this claim, Sapontzis notes that "in addition to relational rights and responsibilities, common morality also contains egalitarian rights and responsibilities." 105 Our legal system is cautious in the delimitation of the moral boundary between legitimate nepotism and simple prejudice. Racial and sex discrimination legislation is perhaps the most obvious example of the requirement of equal consideration of interests in our society.

Moreover, these boundaries are not drawn along lines requiring the reciprocation of the rights accorded, since they are clearly directed to the protection of the "powerless" in their dealings with the "powerful."106 The requirement of disclosure by the potentially insured to the insurer of all material facts ${ }^{107}$ is an illustration from the law of contract of a right possessed by one party to a contract to protect its weaker interests against those of the more powerful party. ${ }^{108}$

Animals, if, at least in some measure, properly the objects of our sentimental concerns, are similarly powerless members of our community whose interests should be protected against the exploitation of the more powerful. It is in our capacity to "imaginatively sympathize"109 with their position that Smith would make this moral judgment.

The extent of that protection from exploitation though is logically dependent on the extent to which our sympathies exist. Smith himself concludes animals to be far from being complete and proper objects of our passions of gratitude and resentment. ${ }^{110}$ A familiar 
criticism of the sentimentalist account of moral judgment has been the difficulty of moving from a study of contingent human desires to posit appropriate standards of human conduct. ${ }^{111}$ Moral considerations appear to be left to depend on desires and attitudes to which each individual may or may not in fact be subject.

The sentimentalist does seek both a universality and objectivity in moral judgment. ${ }^{12}$ Hume, for example, argued that moral sentiments were both natural and universally distributed. ${ }^{113}$ That they are fixed psychological characteristics of human nature derives support from Darwinian evolutionary theory. ${ }^{114}$ The "all-important emotion of sympathy"115 is an adaptive evolutionary feature; a "feeling ... [which] will have been increased through natural selection; for those communities, which included the greatest number of sympathetic members, would flourish best, and rear the greatest number of offspring." 116

Equally difficult to defend is the charge of anthropomorphism in the expression of our natural concerns for the welfare of animals. ${ }^{117}$ Our sympathy is stimulated because we assume the animal to be like ourselves, and in this we fail to recognize the animal's telos: its own nature. In feeling sympathy for the animal we are incorrectly projecting our own human psychology and physiology onto the animal.

While our expanding understanding of the physiology and psychology of the animal kingdom increasingly diminishes the strength of this case, it nevertheless serves to highlight the contention that a sentimentalist account of moral judgment accords no intrinsic value to the animal.

The sentimentalist basis for moral judgment concerning animals appears to be purely instrumental. ${ }^{118}$ Not only does the argument for its contingent nature apparently remove it from the realm of intrinsic considerations, its derivation from the anthropomorphic projection of our own feelings onto animals in the definition of our sympathies firmly suggests its foundation in merely instrumental considerations. Legislation protecting the welfare of animals is merely a means to our own ends, protecting our own sensitivities and sensibilities. It is certainly in this sense that the courts have understood the nature of our sentimental concern for animals.

The sentimentalist account of the animal "entity" laws, apparent in the judicial analyses of their existence, is not only satisfactory for explaining the form that that law has assumed, it also serves to rationalize its existence without recourse to the notion of the intrinsic value of an animal, so contentious in the "animal rights" debate.

In the historical growth and present form of our animal "entity" laws, sentiment has been given significant expression. If the present movement in reform of Australian welfare law should occur exclusively in the context of contemporary rationalistic philosophy, this would be to ignore a most significant aspect of the heritage of our existing law and its inspiration.

The author is Barrister of the High Court of Australia and formerly a member of the Faculty of Law, The Australian National University.

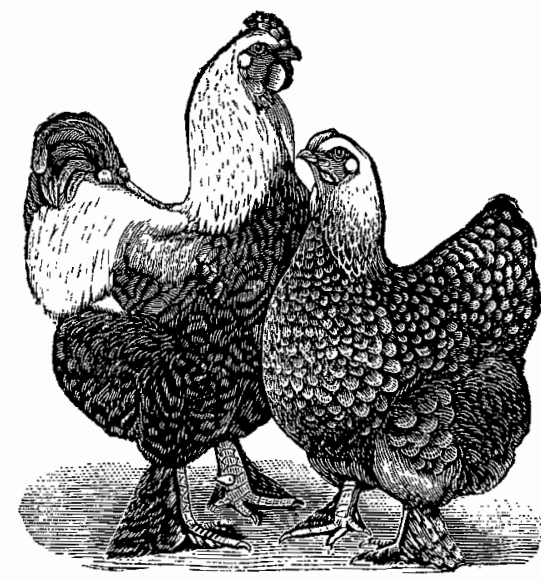

Notes

${ }^{1}$ Now in its 2nd edition: P. Singer, Animal Liberation (New York: New York Review, 1990)

${ }^{2}$ For discussion of this generally, see, for example, $L$. Whyte, Jr., "The Historical Roots of Our Ecological Crisis" (1967) 155 (37) Science 1203-7; P. Singer, op. cit.:; J. Passmore, Man's Responsibility for Nature (London: Duckworth, 1980); J. Passmore, "The Treatment of Animals" (1975) 36 Journal of the History of Ideas 195-218; F. Welbourn, "Man's Dominion" (1975) 73 Theology 561-568; R. Hiers, "Ecology, Biblical Theology, and Methodology: Biblical Perspectives on the Environment" (1984) 19 Zygon 43-59; R. Attfield, "Christian Attitudes to Nature" (1983) 44 Journal of the History of Ideas 369-386; R. Attfield, The Ethics of Environmental Concern (Oxford: Blackwell, 1983); R. Attfield, "Western Traditions and Environmental Ethics" in R. Elliot \& A. Gare, Environmental Philosophy (St. Lucia: 
University of Queensland, 1983) at 210-230; D. Dombrowski, Hartshorne and the Metaphysics of Animal Rights (Albany: State University of New York Press, 1988) at $7 \mathrm{ff}$. S. Kellert and J. Berry, Knowledge, Affection and Basic Attitudes Towards Animals in American Society: Phase III (Washington, D.C.: U. S. Dept. of the Interior, Fish and Wildlife Service, 1982) at 107 consider that the biblical "dominion" of JudeoChristianity provides "potentially useful insights." Their study showed that those who rarely participated in formal religious activities scored far higher on the moralistic and lower on the utilitarian scales than respondents who attended services at least once a week.

${ }^{3}$ R. v. M'Donagh (1891) 28 L. R. Ir. 204 at 212, per O'Brien, C. J., 220, 221, per O'Brien, J.; Ford v. Wiley (1889) 23 Q. B. D. 203 at 210, per Lord Coleridge, C. J.; Grise v. State, 37 Ark. 456 at $456-459$ (1881), per Eakin, J. See further State v.Avery, 44 N. H. 392 at 396 (1862), per Bellows, J.; People v. Brunell, 48 How. Pr. (N. Y. Gen. Sess.) 435 at 437 (1874), per Sutherland, J.; Commonwealth v. Lewis, 21 Atl. 396 at 396 (1891), per Paxson, C. J.

${ }^{4}$ Brady v. M'Argle (1884) 14 L. R. Ir. 174 at 182, per Dowse, B. (quoting Proverbs 12:10). Referring to the "dominion of man" over arimals, Arnold, J. in Stephens $v$. State, 3 So. 458 at 459 (1888) set forth a variety of biblical prescriptions against cruelty to animals in concluding animal cruelty "statutes ... [to] exhibit the spirit of that divine law."

5 V. Routley, "Critical Notice: J. Passmore, Man's Responsibility for Nature" (1975) 53 Australasian Journal of Philosophy 171-185 at 172 .

${ }^{6} I d$. at 173 , commenting that it is possible to reject a vision of the earth in exclusively human terms without being committed to this extreme view.

${ }^{7}$ As to this Bill, see Hansard, (1st. Series), XIV, 553.

${ }^{8}$ Brady v. M'Argle (1884) 14 L. R. Ir. 174 at 183-4, per Dowse, $\mathbf{B}$.

${ }^{9}$ Id. at 182.

${ }^{10}$ R. v. M'Donagh (1891) 28 L. R. Ir. 204 at 214 , per O'Brien, C. J.

${ }^{11}$ Ford v. Wiley (1889) 23 Q. B. D. 203 at 215 , per Lord Coleridge, C. J.

${ }^{12}$ Callaghan v. S. P. C.A. (1885) 16 L. R. Ir. 325

${ }^{13}$ Ford v. Wiley (1889) 23 Q. B. D. 203.

14 See e. g., Hansard (1919) 36 at 525 (Earl of Clanwilliam).
${ }^{15}$ Ford v. Wiley (1889) 23 Q. B. D. 203 (esp. at 215).

${ }^{16}$ Id. at 210, per Lord Coleridge, C. J.

${ }^{17}$ Prevention of Cruelty to Animals Act, 1908 (S.A.), s. 5; Prevention of Cruelty to Animals Act, 1912 (W.A.), s. 5; Animals Protection Act 1925 (Qld), s. 7; Cruelty to Animals Prevention Act, 1925 (Tas), s. 5; Prevention of Cruelty to Animals (Amendment) Act, 1928 (N.S.W.).

${ }^{18}$ See generally infra on "Intrinsic Value."

19 A. Shore, "Religion: Animals" (1987) 23 Animal Liberation: The Magazine 17.

20 Theological considerations do not feature in Animal Experimentation; Report by the Senate Select Committee on Animal Welfare (Canberra: Australian Government Publishing Service, 1989) although the Committee devotes an entire chapter of its report to the moral status of animals (ch. 3).

21 5 \& 6 William IV, cap. 59.

${ }^{22}$ As to this Bill, see Hansard, (1st. Series), XIV, 553.

${ }^{23}$ Commonwealth v. Turner, 14 N. E. 130 at 131-132 (1887), cited in State v. Porter, 16 S. E. 915 at 916 (1893); Commonwealth v. Higgins, 178 N. E. 536 at 537-538 (1931); Ford v. Wiley (1889) 23 Q.B.D. 203 at 216, 225. In Australia, see Martin v. Carpenter (1925) S.A.S.R. 421 at 424, 431, 432 cf. Re Appeals of Ingram (1970) 2 D.C.R. (N.S.W.) 259 at 267; Trenchard v. Ryan (1910) 10 S.R. (N.S.W.) 618 at 621. Recent statements appear in Animal Legal Defense Fund v. Provimi Veal Corp., 626 F. Supp. 278 at 280 (1986); Knox v. M.S.P.C.A., 12 Mass. App. 407 at $409 ; 425$ N. E. 2 d 393 at 396 (1981); Peck v. Dunn, 574 P. 2d 367 at 369 (1978), cert. den. 98 S. Ct. 2822, 436 U.S. 927, 56 L. Ed. 2d 770 (1978). In Commonwealth v. Tilton, 49 Mass. (8 Met.) 232 at 234 (1884), Shaw, C. J. concluded cock-fighting to be an offence even at common law in Massachusetts as "leading to disorder" and "tending to deaden the feelings of humanity." See further S. v. Edmunds 19682 PH H 398 (N).

${ }^{24}$ Re Public Trustee and Toronto Humane Society (1987) 40 D.L.R. (4th) 111 at 128. See further P. Jamieson, "On Charity's Edge - The Animal Welfare Trust" (1987) 13 Monash University Law Review 1-36.

${ }^{25}$ I. Kant, The Groundwork of the Metaphysics of Morals, trans. H. J. Paton (New York: Harper \& Row, 1964) at 76.

${ }^{26}$ I. Kant, "Duties to Animals and Spirits" in Lectures on Ethics, trans. I. Infield (New York: Harper \& Row, 1963) at 240 .

${ }^{27}$ Op. cit. supra n. 25 at 96. 
${ }^{28}$ Op. cit. supra n. 26 at 239.

${ }^{29} \mathrm{Id}$. at $240-241$. On Kant's position as regards animals, see further A. Broadie \& E. Pybus, "Kant's Treatment of Animals" (1974) 49 Philosophy 375-383; T. Regan, "Broadie and Pybus on Kant" (1976) 51 Philosophy 471-472; A. Broadie and E. Pybus, "Kant on the Maltreatment of Animals" (1978) 53 Philosophy 560-561 (reply to Regan); C. Hoff, "Kant's Invidious Humanism" (1983) 5 Environmental Ethics 63-70; T. Regan, The Case for Animal Rights (Berkeley: University of California Press, 1983) at 174- 185.

${ }^{30}$ S. Kellert and A. Felthous, "Childhood Cruelty Towards Animals Among Criminals and Noncriminals" (1985) 38 Human Relations 1113-1129 at 1116. See further A. Felthouse, "Aggression Against Cats, Dogs and People" (1980) 10 Child Psychiatry and Human Development 169-177; A. Felthouse, "Childhood Cruelty to Cats, Dogs and Other Animals" (1981) 8 Bulletin American Academy Psychiatric Law 48-53; M. Heller, S. Ehrlich and D. Lester, "Childhood Cruelty to Animals, Firesetting, and Enuresis as Correlates of Competence to Stand Trial" (1984) 110 The Journal of General Psychology 151-153.

${ }^{31}$ A. Felthous, "Aggression Against Cats, Dogs and People" (1980) 10 Child Psychiatry and Human Developmenl 169-177 at 169 (esp. nn. 2-5, 7).

${ }^{32}$ R. Lockwood, "The Role of Animals in Our Perception of People," (1985) 15 Veterinary Clinics of North America: Small Animal Practice 377-385 at 383.

33 Though R. Nozick, Anarchy, State and Utopia (New York: Basic Books, Inc., 1974) at 36, asking, "Am I not capable of understanding that people differ from baseballs and doesn't this understanding stop the spillover?", considers it a "puzzle" why things should be different in the case of animals.

${ }^{34}$ Noted in J. Turner, Animals, Pain and Humanity in the Victorian Mind: Reckoning with the Beast (Baltimore: John Hopkins University Press, 1980) at 23.

${ }^{35}$ Confirmed as late as 1972 in Flood v. Kuhn, 407 U.S. 258 (1972) (though see Kansas City Baseball Corporation $v$. Major League Baseball Players Association (1976) 409 F. Supp. 233, aff'd. 532 F. 2d 615). See generally J. Bames, Sports and the Law in Canada (Toronto: Butterworths, 1988) at $122 \mathrm{ff}$. In Eastham v. Newcastle United Football Club (1964) $1 \mathrm{Ch} .413$, the transfer system for football players challenged in that case was "stigmatized by the plaintiff's counsel as ... involving the buying and selling of human beings as chattels": Wilberforce J. at 427 . In finding the system (in conjunction with the retention system) to be in restraint of trade, his Honour concluded that "to anyone not hardened to acceptance of the practice it would seem inhuman" (at 427).
36 D. Howell, Letter, (1983) 286 British Medical Journal 1894.

${ }^{37}$ D'Aguiar v. Guyana Commissioner of Inland Revenue (1970) T.R. 31 at 34. See further Jamieson, supra n. 24.

${ }^{38}$ State v. Karstendiek, 22 So. 845 at 847 (1897).

${ }^{39}$ Grise v. State, 37 Ark. 456 at 458-459 (1881), per Eakin, J.

${ }^{40}$ Animal Rights Law Reporter, Oct. 1983 at 2-3.

4134 D. \& C. $2 d 121$ (Pa. 1964).

${ }^{42}$ Senate Concurrent Resolution No. 8, reprinted in (1983) 4 International Journal for the Study of Animal Problems 343. B. Brody, "An Evaluation of the Ethical Arguments Commonly Raised Against the Patenting of Transgenic Animais" in W. Lesser (ed.), Animal Patents: The Legal, Economic and Social Issues (New York: Stockton Press, 1989) at 147 finds the "moral significance" of animal suffering to have also been recognized in recent federal legislation in the United States.

${ }^{43}$ Animal Experimentation: Report by the Senate Select Committee on Animal Welfare (Canberra: Australian Government Publishing Service, 1989) at 42.

${ }^{44}$ South Australian Parliamentary Debates (1985), vol. 2 at 1624 (J. R. Cornwall).

45 Victorian Parliamentary Debates (1986), vol. 382 at 968 (R. I. Knowles).

${ }^{46}$ S. Kellert and J. Berry, Knowledge, Affection and Basic Attitudes Toward Animals in American Society: Phase III (Washington, D.C.: U.S. Dept. of the Interior, Fish and Wildlife Service, 1982) at 44.

${ }^{47}$ Lord Houghton of Sowerby, "Putting Animals into Politics" (1979) 234 Contemporary Review 130-136 at 135.

${ }^{48}$ Op. cit. supra n. 46 at 83,89 .

${ }^{49}$ Anon., "Farm Animal Welfare Poll in Australia" (1981) 2 International Journal for the Study of Animal Problems 171.

${ }^{50}$ Section 1(a).

${ }^{51}$ Prevention of Cruelty to Animals Act 1986(Vict.), s. 6(c).

52 Victorian Parliamentary Debates (1986), vol. 382 at 974-5 (and generally).

${ }^{53}$ South Australian Government Gazette, 24 April 1986 at 1018 (The Pig), 1027 (The Domestic Fowl). See further 
South Australian Government Gazette, 24 April 1986 at $1017 \mathrm{ff}, 24$ July 1986 at $337 \mathrm{ff}$.

${ }^{54}$ N.H.M.R.C., C.S.I.R.O. and Australian Agricultural Council, Australian Code of Practice for the Care and Use of Animals for Scientific Purposes (Canberra: Australian Government Publishing Service, 1990).

$$
\begin{aligned}
& { }^{55} \mathrm{Id} \text {. at 1.2. } \\
& { }^{56} \mathrm{Id} \text {. at 4.5.23. }
\end{aligned}
$$

${ }^{57}$ Article 1. See also Article 3. A recent study of college students in the United States shows most to be concerned about animal pain and suffering, and while supporting the use of animals in research, want increased regulation of these activities: G. Gallop, Jr. and J. Beckstead, "Attitudes Toward Animal Research" (1988) 43 American Psychologist 474-476.

58 R. Dresser, "Standards for Animal Research: Looking at the Middle" (1988) 13 The Journal of Medicine and Philosophy $123-143$ at 128 finds in such legislation the "moderate reform position" that "animals' experiences count for something." She considers that, as "moral concern and pragmatism together inform this position," it has "the highest chance of acceptance at this time" (at 138).

59 J. Tannenbaum and A. Rowan, "Rethinking the Morality of Animal Research" (1985) 15 Hastings Center Report 32-43 at 40.

\section{${ }^{60}$ Cruelty to Animals Protection Act, 1925 (Tas.) s. 4.}

${ }^{61}$ See generally M. Midgely, Animals and Why They Matter (Middlesex: Penguin Books, 1983); J. Livingston, "Righteousness or Rights" (1984) 22:2 Osgoode Hall Law Journal 309-321; Tannenbaum and Rowan, supra n. 59 at 41; J. Tannenbaum, "Ethics and Human - Companion Animal Interaction: A Plea for a Veterinary Ethics of the Human Companion Animal Bond" (1985) 15(2) Veterinary Clinics of North America: Small Animal Practice 431-447 at 441. It is canvassed by F. McMillan, "Perspective on Animal Welfare" (Letter to the Editor) (1984) 185 J.A.V. M. A. 480, 482 in responding to F. Jacobs, "A Perspective on Animal Rights and Domestic Animals" (1984) 184 J.A. V.M.A. 1344 1345. See further J. Baird Callicott, In Defense of the Land Ethic: Essays in Environmental Philosophy (Albany: State University of New York Press, 1989) at 46, 51-59.

$$
\begin{aligned}
& { }^{62} \text { Livingston, } I d . \text { at } 313 . \\
& { }^{63} \text { Ibid. } \\
& { }^{64} \text { Ibid. }
\end{aligned}
$$

65 Tannenbaum and Rowan, supra n. 59 at 41. Interestingly a recent Australian study has shown that "animal liberationists in comparison to hunters attached most importance to the domestic versus wild dimension": D. Fenton and A. Hills, "The Perception of Animals Amongst Animal Liberationists and Hunters" (1988) 23(2) Australian Psychologist 243-257 at 253.

\footnotetext{
${ }^{66}$ See further S. Clark, "The Rights of Wild Things" (1979) 22 Inquiry 171-188.
}

${ }^{67}$ T. Aquinas, Summa Theologiae, trans. D. Bourke and A. Littledale (London: Blackfriars, 1969) 29, 1a 2ae 102.6 at 225 .

68 Ibid.

${ }^{69}$ Johnstone v. Abercrombie (1892) 20 R (Just. Cases) 37 at 44, per Lord Young; Grise v. State, 37 Ark. 456 at 458 (1881), per Eakin, J.; R. v. Moata 1947 (1) SA 490 (o) (translated from the Afrikaans in F. Schweitzer and M. Wood, "The Legal Position Regarding Animal Experimentation in South Africa" (1989) 17 Alternatives to Laboratory Animals 38-39 at 38). In State v. Smith, 21 Tex. 748 at 752 (1885), Hobarts, J. considered animal welfare sufficiently protected in the absence of anti-cruelty legislation by reason of "the prevalent moral sentiment on the subject."

${ }^{70}$ Re Astor's Settlement Trusts (1952) 1 All E.R. 1067 at 1074, per Roxburgh, J.; Re Producers' Defence Fund (1954) V.L.R. 246 at 255 cf. Lindsay's Executor v. Forsyth (1940) S.C. 568 at $571-2$.

${ }^{71}$ Caper's Estate, 34 D. \& C. $2 \mathrm{~d} 121$ at 134 (Pa. 1964).

${ }^{72}$ Infante v. Leith, 85 P.R.R. 24 at 37 (1962); La Porte v. Associated Independents, Inc., 163 So. 2d 267 at 269 (Fla. 1964); Jankoski v. Preiser Animal Hospital, 510 N.E. 2 d 1084 at 1087 (Ill. App., 1 Dist. 1987), appeal denied 517 N.E. 2 d 1086 (1987). See further Paul v. Osceola County, 388 So. 2d 40 (Fla. App. 1980).

${ }^{73}$ No. 225698, Superior Court, San Francisco County, 17 June 1980.

${ }^{74}$ Caper's Estate, 34 D. \& C. $2 d 121$ at 134 (Pa. 1964).

${ }^{75}$ Supra n. 73 at 9.

${ }^{76}$ California Senate Bill 2509 passed unanimously and signed into law on 16 June 1980, noted in F. Carlisle, "Destruction of Pets by Will Provision" (1981) 16 Real Property, Probate \& Trust Journal 894-903 at 894. This comment on the Bill appears Idem. at 897 . See further State v. Smith, 21 Tex. 748 at 752 (1885). 
77 Johnstone v. Abercrombie (1892) 20 R (Just. Cases) 37 at 44, per Lord Young. See further J. Passmore, Man's Responsibility for Nature (London: Duckworth, 1980) at 117.

${ }^{78} \mathrm{~J}$. Feinberg, "Human Duties and Animal Rights" in R. Morris and M. Fox (eds.), On the Fifth Day: Animal Rights and Human Ethics (Washington, D.C.: Acropolis Books, 1978) at 49. See further J. Feinberg, "The Rights of Animals and Unbom Generations" in E. Partridge (ed.), Responsibilities to Future Generations: Environmental Ethics (Buffalo, N.Y.: Prometheus Books, 1981) at 141 and in W. Blackstone (ed.), Philosophy and Environmental Crisis (Athens: University of Georgia Press, 1974) at 45; G. Hughes, "Who is a Victim?" (1974) 1 The Dalhousie Law Journal 425-440 at 426-427.

${ }^{79}$ L. Schwartz, "Morals Offenses and the Model Penal Code" (1963) 63 Columbia Law Review 669-686 at 676.

${ }^{80} \mathrm{~S}$. Kellert and M. Westervelt, Trends in Animal Use and Perception in 20th Century America: Phase IV (Washington, D.C.: U. S. Dept. of the Interior, Fish and Wildlife Service, 1981) at 35.

${ }^{81}$ Id. at 37.

${ }^{82} \mathrm{~S}$. Kellert and J. Berry, Knowledge, Affection and Basic Attitudes Towards Animals in American Society: Phase III, (Washington, D.C.: U. S. Dept. of the Interior, Fish and Wildlife Service, 1982) at 53.

${ }^{83}$ Op. cit. supra n. 80 at 126.

${ }^{84}$ Op. cit. supra n. 82 at 48 . See further J. Serpell, In the Company of Animals: A Study of Human-Animal Relationships (Oxford: Basil Blackwell, 1986) at 29.

${ }^{85} \mathrm{ld}$. at 89,108 . See further M. Fox and L. Mickley (eds), Advances in Animal Welfare Science 1984 (Dordrecht: Martinus Nijhoff, 1985) at 177-195 (esp. at 187).

86 J. Filonowicz, "Ethical Sentimentalism Revisited" (1989) 6 History of Philosophy Quarterly 189-206 at 192.

${ }^{87}$ See, for example, J. Tischler, "Rights for Nonhuman Animals: A Guardianship Model for Dogs and Cats" (1977) 14 San Diego Law Review 484-506 at 484; T. Regan, All That Dwell Therein: Animal Rights and Environmental Ethics (Berkeley and Los Angeles: University of California Press, 1982) at 169. The point is recognized in J. Fisher, "Taking Sympathy Seriously: A Defense of Our Moral Psychology Towards Animals" (1987) 9 Environmental Ethics 197-215 cf. M. Midgley, "Brutality and Sentimentality" (1979) 54 Philosophy 385-389. See further Yi-Fu Tuan, Morality and Imagination: Paradoxes of Progress (Madison: University of Wisconsin Press, 1989) at 170.
${ }^{88}$ See generally B. Rollin, The Unheeded Cry: Animal Consciousness, Animal Pain and Science (Oxford: Oxford University Press, 1989); Callicott, op. cit. supra n. 61; S. Sapontzis, Morals, Reason, and Animals (Philadelphia: Temple University Press, 1987); M. Midgley, Animals and Why They Matter (Middlesex: Penguin Books, 1983); S. Clark, The Nature of the Beast: Are Animals Moral? (Oxford: Oxford University Press, 1982) cf. P. Wenz, Environmental Justice (Albany: State University of New York Press, 1988). See further J. Benson, "The Duty and the Beast" (1978) 53 Philosophy 529-549; B. Steinbock, "Speciesism and the Idea of Equality" (1978) 53 Philosophy 247-256 at 255-256; J. Narveson, "Animal Rights" (1977) 7 Canadian Journal of Philosophy 161-178 (esp. at 177); W. Davis, "Man-Eating Aliens" (1976) $10 \mathrm{Jnl}$ Value Inquiry 178-185. On sympathy, see M. Fox, "Empathy, Humaneness and Animal Welfare" in M. Fox and L. Mickley (eds.), Advances in Animal Welfare Science 1984 (Dordrecht: Martinus Nijhoff, 1985) at 61-73; Fisher, Ibid.; R. Ryder, "The Struggle Against Speciesism" in D. Paterson and R. Ryder (eds.), Animals" Rights: A Symposium (Sussex: Centaur Press, 1979) at 13.

${ }^{89}$ J. Mackie, Hume's Moral Theory (London: Rouledge \& Kegan Paul, 1980) at 120ff; P. Mercer, Sympathy and Ethics: A Study of the Relationship Between Sympathy and Morality with Special Reference to Hume's "Treatise" (Oxford: Clarendon Press, 1972) at 85ff.; T. Campbell, Adam Smith's Science of Morals (London: George Allen \& Unwin, 1971) at $94 \mathrm{ff}$.

${ }^{90}$ Mackie, Id. at 120 . See further B. Barry, A Treatise on Social Justice (vol. 1): Theories of Justice (London: HarvesterWheatsheaf, 1989) at 158-159.

${ }^{91}$ Mercer, op. cit. supra n. 89 at $85 \mathrm{ff}$; Campbell, op. cit. supran. 89 at $94 \mathrm{ff}$.

${ }^{92}$ Op. cit. supra n. 74, 8k. II, Part I, Sect. XI at 319.

${ }^{93}$ D. Raphael and A. Macfie (eds.), A. Smith: The Theory of Moral Sentiments (Oxford: Clarendon Press, 1976) at 9.

${ }^{94}$ For example, Grise v. State, 37 Ark. 456 at 459 (1881), per Eakin, J. See further O. Quinlan, "Animals - Have They Rights?" (1894) 38 Central Law Journal 160-166 at 162.

${ }^{95}$ Ibid.

${ }^{96}$ I. Selby-Bigge (ed.), D. Hume: A Treatise of Human Nature, revised by P. Nidditch (Oxford: Clarendon Press, 1978) Bk. III, PartI, Sect. I at 469.

${ }^{97}$ D. Hume, "An Enquiry Concerning the Principles of Morals" in D. Hume, Enquiries Concerning Human Understanding and Concerning the Principles of Morals, text 
revised and notes by P. Nidditch (Oxford: Clarendon Press, 1975, reprinted from the posthumous edition of 1777) Sect. III, Part I, 152 at 190 . Useful discussions of Hume's position with respect to animals appear in Barry, op. cit. supra n. 90 at 161-163, 203; L. Brown, Cruelty to Animals: The Moral Debt (Hampshire: Macmillan Press, 1988) at 67-68; A. Baier, "Knowing Our Place in the Animal World" in H. Miller and W. Williams, Ethics and Animals (New Jersey: Humana, 1983); M. Seidler, "Hume and the Animals" (1977) 15 Southern Journal of Philosophy 361-372.

${ }^{98}$ Op. cit. supra n. 93 at 95.

${ }^{99}$ Ibid.

$100 \mathrm{Id}$. at 96.

${ }^{101}$ Id. at 95 .

${ }^{102}$ Grise v. State, 37 Ark. 456 at 459 (1881), per Eakin, J. See further O. Quinlan, “Animals - Have They Rights?" (1894) 38 Central Law lournal 160-166 at 162.

${ }^{103}$ S. Sapontzis, "Moral Community and Animal Rights" (1985) 22 American Philosophical Quarterly 251-257 at 255.

${ }^{104}$ L. Becker, "The Priority of Human Interests" in H. Miller and W. Williams, Ethics and Animals (New Jersey: Humana, 1983) at 238. See also Benson, supra n. 88 at $536-537$ cf. S. Sapontzis, "On Justifying the Exploitation of Animals in Research" (1988) 13 The Journal of Medicine and Philosophy 177-196 at 182-183.

105 Supra n. 103.

${ }^{106}$ Id. at 252 raises this point in attacking a reciprocity requirement in the ascription of moral rights.

${ }^{107}$ Carter v. Boehm 3 Burr 1905; 97 E. R. 1162 (1766).

${ }^{108}$ Although note that the obligation uberrima fides is bilateral: Guardian Assurance Co.Ltd v. Condogianis (1919) 26 C.L.R. 231 at 237. The obligation merely usually arises in the context of the party seeking insurance.

${ }^{109}$ Campbell, op. cit. supra n. 89 at 96 , referring to Smith's Theory of Moral Sentiments. On this, see op. cit. supra n. 93 at $16 \mathrm{ff}$.

${ }^{110}$ Op. cil. supra n. 93 at 95.

111 J. Filonowicz, "Ethical Sentimentalism Revisited" (1989) 6 History of Philosophy Quarterly 189-206 at 192. The difficulty is acknowledged, for example, in T. Nagel, The Possibility of Altruism (Princeton: Princeton University Press, 1970) at 3-5. See further D. Chismar, "Empathy and
Sympathy: The Important Difference" (1988) $22 \mathrm{Jnl}$ Value Inquiry 257-266; T. Regan, "Narveson on Egoism and the Rights of Animals" (1977) 7 Canadian Journal of Philosophy 179-186 at 183; T. Regan, The Case for Animal Rights (Berkeley: University of California Press, 1983) at 160.

112 J. Filonowicz, "Ethical Sentimentalism Revisited" (1989) 6 History of Philosophy Quarterly 189-206 at 202.

${ }^{113}$ Op. cit. supra n. 96, Bk. III, Part I, Sect. II at 474-475. See further Barry, op. cit. supra n. 90 at 167-168.

114 Noted in J. Baird Callicott, "Hume's Is/Ought Dichotomy and the Relation of Ecology to Leopold's Land Ethic" (1982) 4 Environmental Ethics 163-174 at 165-166.

115 C. Darwin, The Descent of Man and Selection in Relation to Sex (London: John Murray, 1875) at 106.

${ }^{116} \mathrm{Id}$. at 107 . See further though on the relationship of morality and evolution C. McGinn, "Evolution, Animals, and the Basis of Morality" (1979) 22 Inquiry 81-99.

117 See, e.g., though J. Fisher, "Taking Sympathy Seriously: A Defense of Our Moral Psychology Towards Animals" (1987) 9 Environmental Ethics 197-215. See further S. Richards, "Forethoughts on Carnivores" (1981) 56 Philosophy 73-87 at 79.

118 This is noted in G. Carson, Men, Beasts and Gods: A History of Cruelty and Kindness to Animals (New York: Charles Scribner's Sons, 1972). See further R. Hanula \& P. Hill, "Using Metaright Theory to Ascribe Kantian Rights to Animals Within Nozick's Minimal State" (1977) 19 Arizona Law Review 243-283 at 271. 